DOI: $10.1515 /$ pof-2015-0017

VOLUME 7, ISSUE 3, 2015

ISSN: $2036-5438$

\title{
Eurocrisis and the myths of European redistribution: illegitimate, unsustainable, inefficient?
}

by

Francesco Nicoli*

Perspectives on Federalism, Vol. 7, issue 3, 2015 


\begin{abstract}
Criticism of European solidarity relies on three cornerstone arguments with mythological features. First is the "Myth of the Beggar": it is believed that supranational solidarity is self-defeating, as it produces a moral-hazard scheme where endogenous incentives to reform (otherwise known as "market pressure") are artificially removed. Second stands the "Myth of the Efficient Markets": it is believed that solidarity, through its market-distortive effects, artificially allocates resources into less productive activities, thus decreasing the overall growth rate of the economy. Third is the "Myth of the Demos": it is believed that democracy- and thus redistribution- can endure only within a single Demos, and thus no solidarity can exist outside of a Demos. This paper aims to challenge the view that any scheme of solidarity is self-defeating, inefficient and illegitimate, developing a notion of "federative solidarity" providing a solution to the three "myths".
\end{abstract}

Key-words

Solidarity, Redistribution, moral-hazard, federation, Eurocrisis, European Union, trilemma, demos 


\section{Redistribution and solidarity in the Eurocrisis}

Since late 2010, the Euro Area is torn by an economic, financial, political and -most of all- existential crisis. The great divide between core and peripheral countries in the monetary union threatens the very existence of European integration as we know it; yet, despite the overreaching consensus among the majority of economists concerning, on the one hand, the policy overhaul needed in the peripheral countries, and on the other, the institutions needed at European level to fully address the crisis, the progresses have been painfully slow and associated with high social costs. A truly integrated fiscal and economic Union is deemed to permanently address the causes of the Eurocrisis; yet, its implantation is delayed because of political opposition to further integration. Solidarity and sovereignty are at stake. The reason is simple to understand, but challenging to address. As originally stated by Mundell $(1960,1961)$ and more recently, among many other scholars, by De Grauwe (2011; 2013) Enderlein (2012) and Pisani-Ferry, Vihriälä and Wolff (2013), a monetary union requires, implicitly or explicitly, a fiscal and economic union. In fact, this is known since the Werner Report (1970); since the Van Rumpuy "Four presidents' Report" (2012), the strengthening of the monetary union with an economic and fiscal pillar is formally a flagship policy of the EU, and has acquired a more detailed timeline in the “Five presidents' report" (2015).

More in detail, Merler and Pisani-Ferry (2012) show that, in order to permanently settle the Eurocrisis, a choice is to be made between a full-fledged banking union, a debt union, and a stabilization mandate for the ECB. However, the three options all imply, in fact, fiscal integration (Nicoli, 2015): a full-fledged banking union implies the construction of a credible guarantee on deposits, which, by definition, has fiscal implications because it ultimately relies on sovereign funding (Wolff and PisaniFerry, 2012); a fiscal union (either in the form of Eurobonds or as a form of transfer mechanisms among states) is by definition a form of fiscal union; and a properly stabilizing mandate of the ECB has redistributive implications both in "normal times", when member states pay back to the bondholders their rates (De Grauwe and Ji, 2013 A) and in crisis times, when eventually a member state defaults on its bonds held by the ECB (Sinn and Wollmershäuser, 2011). The fiscally non-neutral nature of monetary integration is also evident by the intra-EU payment 
system of the Eurozone, TARGET II, which regulates claims and liabilities of national systems vis à vis the remainder of the Eurosystem. While TARGET II balances are fiscally neutral as long as the Euro is in place for all the participating countries, they become justiciable claims if a country were to leave the Eurosystem; as a consequence, we can consider that the Euro has had fiscal implications since its inception, which have become apparent under the fist of the crisis. Fiscal integration, broadly speaking, is as much an implicit feature of the construction of the Eurozone as it is a requirement for its long term preservation. The actual form fiscal integration will acquire (a full-fledged banking union, a fiscal union, an "ECB-stabilized" union, or a combination of these features) is still unclear, but nevertheless fiscal and economic integration is by any account, in the making.

In the economy of this paper we thus define, as the operative condition for the Euro Area to be stabilized and thrive, the creation of a permanent system of transfers which disbursement is not to be subject, at each time, to unanimous approval. The creation of such permanent system does not imply that the transfers have to be, themselves, permanent, or that they shall be unconditional; but once the system is agreed upon and conditions are set, the factual disbursement of resources does no longer constitute a matter of political discretion among member states. Such evolution would constitute a "genetic change" for the EU, which so evolves from a regulatory polity (Majone, 1999) to a redistributive one (Majone, 2014). In fact, a fiscal union of any kind implies a degree of redistribution, which cannot be achieved without a pre-existing predisposition to solidarity among the participants. But the "old" understanding of solidarity in the European Union was referred to the idea of inter-national solidarity; the kind of solidarity required for a fiscal and economic union is, on the other hand, typical of communities or nation states.

Solidarity is a central feature of modern all European societies (the so-called "European Social Model"), and -in its most general definition- it can be intended as the transfers of resources to those in need without expecting a positive monetary return. ${ }^{\mathrm{I}}$ When these societies have convened together to establish a permanent, incremental process of integration (as in the case of the European Union) they have however decided to accompany the national vision of solidarity with a newly-minted notion of inter-national solidarity. International solidarity stems from the same conceptual definitions as national solidarity, but it is applied differently as it concerns different nations. While national solidarity is anchored in communitarian bonds, international solidarity has originated as a 
form of contractual relation, a juridical connection between state-subjects (Brukhost, 2005). During the crisis, nevertheless, calls for generic "solidarity" have multiplied. As it is defined by its promoters, the new "European" solidarity is neither national nor inter-national; it is instead best defined as supra-or post-national (Habermas, 2013).

Of course, this is no new trend: if we assume, along with Derpmann (2009), that social rights constitute a crystallized expression of solidarity, then —at least since Kant - there has been a tendency to develop a global theory of solidarity. Unfortunately, these efforts have reached three dead-ends: human-rights Cosmopolitanism, Redistributive Global Justice and Transnational Solidarity. The first approach(human rights cosmopolitanism), by far the most advanced and recognized application of global solidarity thinking, has succeeded to develop a legal doctrine of human rights but failed in approving global social rights with redistributive dimension. The second approach -Redistributive Global Justiceremains highly theoretical and has never been practically implemented. The third approach "transnational solidarity" (as suggested by Gould, 2007) in practice boils down to safety nets in case of natural disasters or other temporary critical junctures, thus falling into the notion of inter-national solidarity despite the fancy new label.

Against this background, this paper argues that for supranational solidarity to exist, it must in fact be constituted by a linear combination of national and international solidarity: it cannot be simply intended as national solidarity applied internationally. Indeed, simply applying the national concept of solidarity among different nations generates a set of problems which can be (theoretically) neglected at national level. The particular nature of the Eurocrisis and of the ensuing European solidarity does produce -within the public debate- the ideal conditions for the emergence of old -yet often discussed-issues regarding solidarity, in particular the Moral Hazard and the optimal resources allocation. These issues used to be "hidden", or largely neglected, when discussing the national and inter-national versions of solidarity, but become apparent again when discussing European solidarity.

To understand how European solidarity differs from national and international solidarity altogether and why "new" issues arise, it is first required to clarify the distinctions between these two classical concepts. When comparing fiscal integration schemes in the frame of the Eurocrisis, four conditions are to be met; the scheme must be (1) effective in solving the crisis; (2) legitimate in front of the constituencies; (3) sustainable to avoid freeriders and moral hazard issues; and (4) efficient in allocating resources. The paper is thus 
organized as follows: section 2 deals with clarifying the concepts of national and international in respect to each other. Section 3 deals with the "myth of the demos", which constitutes the "shroud" behind which issues like moral hazard are hidden in the national context." Section 4 deals with "the myth of the beggar", discussing the validity of Moral Hazard in supranational solidarity; Section 5 deals with the "myth of the efficient markets". The conclusions (section 5) collect the results of the previous sections and set the conditions required for European solidarity to be sustainable, effective and legitimate.

\section{National and intern-national solidarity in the European legal framework}

Solidarity has played a fundamental role in discourse framing since the beginning of the European crisis. In particular, it has been used both as a means to justify - in front of national parliaments and up to a certain extent- new institutions and policies (Closa and Maatsch, 2014) and as a catchword used by fringe groups on the extremes of the political spectrum to oppose ruling parties during elections. It is worth noting that, in the latter case, the frame has acquired both a negative and a positive meaning, depending on whether the ruling elites were accused of having shown "too little" or "too much" solidarity towards southern European countries most hit by the crisis. Kontochristou and Mascha (2014) provide a definition of solidarity based on Durkheim (1893), for whom solidarity is intended as a society's criterion for determining a social group's boundaries.

Modern national solidarity can be understood as having roots in both pillars of Durkheim's solidarity typology: it is "mechanic" (or national) because it applies within the limits of a national community and weakens when extended further; and it is "organic" because it is mediated by state institutions (Gould, 2007). Applying Durkheim's understanding of solidarity is however problematic when considering the nature of solidarity relations within the European polity. A strict adherence to the national-organic view of solidarity (and distributive democracy as a related concept) will eventually collapse into the no demos thesis discussed in detail in the next section of this paper. We define national solidarity as a non-conditional solidarity among members of the same national group; typical examples of national solidarity are represented by the building blocks of a national welfare system with redistributive features. Typically, national solidarity is 
(generally) individual, automatic and unconditional, meaning it is often activated when an individual reaches a certain disadvantaged status vis àvis the other members of the national community, and will maintain the benefits of solidarity as long as it remains in the disadvantaged status. Within national federal polities the individualistic solidarity is often accompanied by a community-level system, where the region/state, and not the individual, is the target subject; in this case we also observe a relaxation of the non-conditionality features of national solidarity, as it happened in the federal republic of Germany since the introduction of the two "federation reforms" in 2005 and 2009.

In contrast, the European legal and philosophical tradition is characterized by a major distinction between national and inter-national solidarity. While the former constitutes a pre-requisite for democracy (Weiler, 1996), the latter is an ad-hoc mechanism to deal with limited problems and shall arise in special occasions. An inter-national solidarity clause is enshrined in art.122 of the Treaty on the Functioning of the European Union and is to be activated in case of natural disasters and disruptive events beyond a member state responsibility and control. As such, anti-crisis measures are not directly concerned by the solidarity notion as developed within the Treaties: the amendment of article 136 TFEU carried out in 2011 (allowing for the creation of a permanent financial aid mechanism in the Euro Area) has no references to solidarity as a driver for its activation, but rather its creation is justified in term of ensuring the endurance and the stability of the Eurozone.

The exceptionality of inter-national solidarity (as opposed to national solidarity) is also evident from the recent Bundesverfassungsgericht judgement on the ESM (Bundesverfassungsgericht, 2012): para. 214 of the decision specifies that, even when large disbursements are required to preserve stability of the Eurozone under ESM or similar mechanisms, they constitute a form of inter-national solidarity and thus they must be approved, case by case, by the Bundestag. Inter-national solidarity is thus defined, in contrast with intra-national solidarity schemes, for its absence of automatism. National Parliaments maintain total discretion on the disbursements enjoying de facto a veto-power. Clearly, this kind of approach is of little help when dealing both with urgent crisis management decisions (which require quick decision making and "anchoring" of financial markets' expectations through appropriate communication) and with the common fiscal policies required to stabilize the Eurozone over the normal economic cycles. Moreover, this conceptual distinction is particularly important in light of the "moral hazard" paradox 
discussed in the fourth section of this paper, as well as for the no demos thesis discussed in the third. As we will show, the two are intimately linked, but the former does not constitute a problem in neither international nor national solidarity, while it arises in supranational schemes.

\section{Solidarity and national identity: "The Myth of the Demos" and the boundaries of redistribution}

\subsection{The myth of the demos in the European context}

One of the most diffused arguments against the creation of a European fiscal and economic union (which would permanently solve the crisis) is that such a solution entails redistribution of resources outside of the nation. The relationship between redistribution and collective identities has noble fathers in political philosophy (Nicoli, 2015:8): in the nineteenth century, it appeared as a corollary in David Hume's Treatise, whereby the "moral feelings" of a human being for the others increase in strength with proximity (Cohon, 2001; 2010, para. 7). It follows that, accordingly with Hume's approach, solidarity manifests itself as a function of proximity. In the German scholarship, this idea was originally developed by Tönnies' gemeinschaft concept, indicating the predominance of societies built on identities and shared beliefs rather than upon contractualism. In the Anglo-Saxon scholarship the debate concerning solidarity, identity and the limits of redistribution has been particularly rich in North America, being marked by contributions like Rawls' “A theory of Justice” (1971), MacIntyre's “After Virtue” (1981) and Walzer's "Spheres of Justice" (1983). The debate was then transferred back on the shores of the Old Continent thanks to the controversial 1993 Maastricht decision on the Bundesverfassungsgericht, and the overall argument -'there cannot be solidarity, and thus democracy, outside of a single Demos'- started to be known as the "no-demos thesis". Among its original proponents were Bryde (1994), Kielmansegg (1994; 1996), and, in a lesser extent, Grimm (1995) and Zürn (2000).

The reasoning proceeds as follows: identity is required for solidarity/redistribution, which is required for democracy (Weiler, 1996; 2000). In the European context, the no demos thesis is particularly important to understand the opposition of several scholars (along with many political parties such as the French Front National or the Italian Lega Nord) to 
the creation of a full-fledged European Democracy: 'Majoritarian decision-making is hardly achievable beyond the national level since it requires some form of collective identity that includes trust and solidarity, (Zürn 2000:195). Although only few among the proponents of the thesis, like Bryde (1994) venture far enough to claim that the conditions for a demos to exist can be found only within coherent ethnical, linguistic and cultural communities, the majority of the scholars sharing the no-demos thesis acknowledge that these elements are indeed essential for creating a sentiment of solidarity among the demos members, thus legitimizing redistribution through majority voting.

It is worth noting that the no-demos thesis produces tangible effects in our institutions regardless whether we agree with the theoretical foundations on which the theoretical argument is built upon. The operational consequence of the Myth of the Demos is that redistributive policies must be agreed democratically, i.e. by majority voting: this is a substantial difference from the classical international doctrine, where redistributive decisions are taken by consensus, i.e. by unanimous approval of each of the participants. This distinction is essential, as it enables policies that can address the Eurocrisis effectively. As outlined above, however, the Bundesverfassungsgericht (2012) has clearly rejected the idea that redistributive policies can happen in the EU trough majority voting (of the states); for each transfer, the ad-hoc approval from the Bundestag is needed, and by mirroring, the other Courts retain the same rights for each national Parliament, thus creating a system where the unanimous consensus of the involved actors is needed. ${ }^{\text {III }}$

\subsection{The no-demos thesis, democracy and redistribution}

Clearly the "Myth of the Demos" appears unproblematic only when we look at national-organic solidarity. The nation, at least as a theoretical construct, fulfills the criteria for solidarity to exist, and its intensity is reflected into States' organization and Constitutions; federal states tend to have lower (unconditional) transfer schemes, which are the expression of national solidarity as classically intended. It remains to be seen, however, to what extent this constitutes, on the one hand, a political-philosophy and constitutional fiction and, on the other hand, to what extent this is a true feature of our societies. Also, the ultimate consequences of a strict adherence to the myth of the demos are yet to be explored. In particular, many questions remain open: several existing nation states in Europe suffer from the threat of internal separatism; are these legitimate claims just in 
name of any historical demos? Is autonomy and self-government a right belonging only to historically-defined demoi or any group of people is endowed with the right of defining itself as a demos thus becoming eligible to sovereignty and to the power of calling themselves out of any form of solidarity agreement? To the roots, the origins of the myth of the demos boil down to understand the limits of self-determination of people, which- at least in international law- is severely limited. ${ }^{\mathrm{IV}}$

On the other hand, the no demos thesis does not constitute an existential threat for schemes of inter-national solidarity, which are by definition non-automatic and ad hoc mechanisms whose deployment is completely subject to the willingness of the contributors to participate. There is no demos issue in inter-national solidarity, as there is no democratic (i.e., majoritarian) redistributive policy. In the inter-national arena, acts of solidarity are an expression of sovereignty of the Parliament, whereby national solidarity is an expression of the sovereignty of the demos standing above its citizens. As long as we maintain this approach of understanding identity as a precondition of transfer schemes, however, the issue of the demos becomes unsolvable in the European context. For the Monetary Union to survive we need indeed a form of fiscal union, which cannot be conditional to a constantly reiterated and unanimous approval of all participating parliaments; the Monetary Union requires a nation-like kind of solidarity, among citizens and not among states; but such kind of solidarity is impossible outside of the demos if we take the demos thesis as it stands.

\subsection{The demos thesis and the crisis}

Clearly, the demos shines in its full albedo when discussing the need for legitimacy for fiscal integration in Europe. In section I we pointed out that fiscal integration is unavoidable. However, on the basis of the demos thesis discussed hereby, the only possible form of legitimization of fiscal policies at EU level would be -adopting Scharpf's (1970) typology- through output legitimacy (i.e. through the benefits provided by the common policies) rather than through input legitimacy (i.e. through the election of the decision makers). Majority-voting democracy may be the most notable victim of the demos thesis, which pushes Europe in a clear-cut trilemma (Nicoli, 2015, figure 1). Differences with apparently similar trilemmas proposed by Rodrik (2011) and Crum (2013) are discussed in the endnote. ${ }^{\mathrm{V}}$ 
According to the legitimacy trilemma, if we take the demos thesis as a given, then we either have to choose whether to pursue fiscal integration in a non-democratic framework, or to make a step back and give up monetary integration. In the former case, the respect of national sovereignty is, of course, largely fictional: it is exactly in the attempt to formally respect the principle that the EU has not obtained true fiscal powers and has delegated its crisis-management policies to unelected non-majoritarian institutions such as the ESM or the IMF; it is in accordance with the formal respect of national sovereignty that the new fiscal treaty (the TSCG) had to be adopted in a purely inter-governmental framework.

\begin{tabular}{|l|l|}
\hline Legitimacy Trilemma \\
\hline Source: Nicoli (2015)
\end{tabular}

In the instant we respect national sovereignty on common fiscal matters, sovereignty itself has to disappear the instant later through "constitutionalization" of the new common policies in order to maintain their credibility and effectiveness. Since Majone (1999), this approach has been known as "insulation"- a strategy to increase effectiveness and credibility of agencies and regulatory policies by minimizing political influence. As Majone (2014) acknowledges, however, fiscal policies are qualitatively different from regulatory policies; insulation of the latter may strengthen their output legitimacy by making them more efficient, but insulation of the former will undermine fundamental democratic legitimacy. 
One of the reasons behind this paradox is that the combination of fiscal integration and the demos thesis have to be output-legitimized by necessity which means that results should be positive in all countries in all periods. Provided that this is unlikely to happen (preferences concerning favorite outcomes can be time -and space- inconsistent), the only way out developed by classical sovereignty theory is the constitutionalization of the agreement through an international treaty, which is an expression of national sovereignty as much as a bond on the change of national preferences. The fiction of national sovereignty, and its underlying demos thesis, is thus maintained at the expenses of factual democracy, reduced to a mere confirmation, at national level, of decisions adopted elsewhere. On the contrary, a democratic, input-legitimized fiscal union would maintain democracy and solve the Eurocrisis, at the cost of overcoming national identities. Are European democracy (and Europe altogether) therefore condemned to fall under its identity divisions? While at a first glance it could seem so, a more detailed reading of the demos thesis, in fact, provides hints of the contrary. The demos thesis is constituted by three distinct bits of argumentation. First comes the causal relation between the identity of the demos, solidarity and democracy: democracy implies redistribution which requires solidarity which requires a shared identity within the demos. Second comes a positive statement: Europeans are not a demos. Last we find, in some authors, a normative statement: Europeans shall not become a demos (Weiler, 2004). Weiler's reasoning is suggestive of one way to paradoxically solve the problem: the foundative telos of Europe, its shared identity, is precisely the respect of the differences, i.e. a constitutional tolerance; by respecting the differences between its constitutive demoi, Europe creates its common identity and constitutional order. Weiler's approach to the dilemma is echoed in Nicolaidis (2013) demoi-cracy approach to the EU. In Nicolaidis' vision, the different demoi maintain their precise nature in respect to the others, but they are bound to each-other by a mutual duty of solidarity and collaboration. Demoi are not fully separate, nor merged in one single entity; redistribution is to happen, but in a way that is radically different from redistribution within nations, and among nations. While Nicolaidis' demoi-cracy and Weiler's Constitutional Tolerance are interesting and challenging principles, the latter fails to provide a practical answer to the urgent need of fiscal integration and economic coordination Europe is today facing, which may require to exert taxation and economic policy across different demoi even if a majority of voters within one of the constituencies opposes it. Similarly, demoicracy is all but clear in setting the boundaries of shared economic 
and fiscal policy-making. Both, moreover, don't address the issue of a common European identity, but suggest that integration may be preserved (let alone strengthened) without it.

\subsection{Federative solidarity}

A different approach to overcome the no-demos thesis is instead possible. The foundative logics of the argument is that the undeniable link between identity and solidarity is that the former is a condition for the latter. It is reasonable, however, to assume that identity and solidarity are co-determined: we feel part of a community because there is a practice of solidarity among its members. Failing to achieve mutual solidarity destroys trust within communities, ultimately dismantling identity. Such inversion of the reasoning echoes a long-standing debate in constitutional law, the egg-and-chicken discussion concerning whether it is the demos which gives itself a Constitution, or the individuals that, through the Constitution, establish themselves into a demos. If the two variables (identity and solidarity) are co-determined, however, none come first but both are jointly and simultaneously established. When two variables are co-determined, an interesting situation (at least in game-theoretical perspectives) emerges: both "bad" equilibria and "good" equilibria are in fact possible, as each of the agents react to the strategic choice of the others. In a "bad" and "good" equilibrium game, i.e. in each situation when two variables are co-determined, institutions and rules are key to push agents towards the "good" equilibrium. An appropriate set of rules about solidarity on the one hand, and fiscal responsibility on the other, may create a positive dynamics where the no-demos thesis is overcome by the mutual trust embedded in a joint effort of responsibility and solidarity. We are saying in fact: there is no European demos yet, but if we create appropriate institutions which build mutual trust through responsibility and solidarity, we will lay the foundations for a European identity to emerge. We Europeans we cannot achieve, just yet, a national federal solidarity; but we can endow ourselves with a federative solidarity which eventually will create a strong feeling of common belonging. By repeating over time the trust-by-solidarity game, Europeans will gain their own identity. The reciprocal generosity-vs-responsibility should provide sufficient output legitimization in the early stages of the process, while building a shared identity which could work as a basis for input legitimization farther on the way. Moreover, as the next sections will show, Federative solidarity -as a co-determination of solidarity and mutual responsibility- constitutes the precondition for a stable solution to the Eurocrisis 
which cannot be achieved under the national-organic and international paradigms of solidarity.

\section{Redistribution, sustainability and moral hazard: "the myth of the beggar"}

\subsection{The Samaritarian dilemma}

The second leading argument against European-wide transfer systems is the so-called "moral hazard", also known as the 'Samaritarian Dilemma' (Buchanan, 1975). In general words, a situation of moral hazard stems from information asymmetry: if an agent $a$ pays, unconditionally, a sum to a recipient $b$ at any moment agent $b$ is in a status of need, agent $b$ will have little or none incentive (if the sum is large enough) to make an effort to solve its own negative situation or even attempt to prevent running in the situation of need. This rough description of moral hazard can be labeled as 'Samaritarian Dilemma' or, in the narrative of this paper, "the myth of the beggar". VII The idea that the core countries should not provide financial assistance to peripheral countries because, if this were to happen, market pressure would disappear and peripheral countries would have little incentive to implement reforms, has been a recurrent theme of the political debate since before the inception of the monetary union (see, for instance, De Grauwe, 2003). This debate has intensified since the beginning of the crisis, as testified by the words of the President of the Bundesbank Mr. Weidmann in relation to the introduction of Eurobonds:

'Croire que les eurobonds résoudront la crise actuelle est une illusion. (...) On ne confie pas sa carte de crédit à quelqu'un si on n'a pas la possibilité de contrôler ses dépenses.'

(Weidmann, interview with Le Monde, May 25 ${ }^{\text {th }}, 2012$ )

More in detail, two versions of the moral hazard can be individuated: the mathematical logics of moral hazard can be qualified either in the classical ex ante "insurance" game, or as an ex post "bail-out" game. In the insurance game, an agent covered ex-ante by an insurance against the potential negative consequences of a risky but profitable behavior has an incentive to undertake the risks as the expected profits are high and the losses are 
socialised (Dowd, 1982). Moral hazard explanations have flourished both during the US financial crisis (see for instance Dowd, 2009) and the European crisis (Alt, Lassen and Wehner, 2012). In macroeconomic terms, the existence of a centralized automatic insurance mechanism against shocks implies that -if no conditionality is attached, as is often the case within nation states- temporary shocks may become permanent because the presence of automatic stabilisers removes the incentive for adjustment (De Grauwe, 2003: 10). The same applies to the ex-post version, in which an agent receives a certain amount of resources for undertaking a given project (for example a reform or a stabilization programme) but once it has received the sum it finds it would be better-off by not investing the resources in the project (Stiglitz and Basu, 2012).

\subsection{The myth of the beggar and the Eurocrisis}

Clearly, moral hazard is one of the main concerns when looking at redistributive measures with solidaristic features. However, national systems tend to overlook the issue: within one single national polity, moral hazard often turns out to be an accepted risk. As noted by Habermas (2013), national-organic solidarity emerged as reaction to the modern "class struggle" on the one hand, and national differentiation on the other. In fact nationalorganic solidarity schemes are in general "permanent" (meaning that they are usually not established to deal with exceptional, short duration issues, but to fulfill a redistributive and equalizing mission) and they are "automatic", meaning that they often have no active conditionality attached on the side of the recipients. Thus, they provide the ideal conditions for moral hazard without it constituting a problem. The costs of solidarity associated with moral hazard are accepted on behalf of the demos, for which -in theory- the community grants its support to the disadvantaged individuals unconditionally. ${ }^{\mathrm{VIII}}$ In contrast, international solidarity schemes are set to deal with specific situations through ad-hoc measures, and are often attached to strict conditionality. There is no socialization of the costs on behalf of the common belonging to the demos, and thus -as suggested by De Grauwe (2003), conditionality must be introduced. The framework for European financial assistance, as created since 2011, fits rather well in the classical paradigm for inter-national solidarity, despite the lack of a formal treaty basis; the reform of the TSCG introduced in 2011 and finally approved in 2013 explicitly refers to "strict conditionality" (art. 136), and the practice of bail-out programmes for Cyprus, Greece, Ireland, Spain and Greece have all 
been anchored into memoranda of understanding inspired by long-standing IMF practice. When the discussion moves on solidarity as a mean to address (and, in economic terms, stabilize) the Eurocrisis, however, it is clear that inter-national solidarity schemes would not fulfill their task: as pointed out by the Bundesverfassungsgericht in 2012 any disbursement shall not be permanent and approved, case by case, by the Bundestag; similar requirements are expected to be raised by other constitutional Courts across the Euro Area.

Provided that confidence is essential for any fiscal stabilization effort (Draghi, 2015 B, among others), any stabilization instrument which capacity to deliver is subject to the will of each parliamentary majority in each parliament at each time the mechanism is activated, is of little use. In other words, classical inter-national solidarity schemes are deemed not to work, or being largely insufficient, as stabilization mechanisms in a monetary union. Other proposed stabilization instruments, like the creation of Eurobonds to mutualize the debt stock, the emission of Eurobills to jointly finance expenditure, the enlargement of the mandate of the ECB to directly intervene on primary markets, and the creation of a common unemployment insurance all have features borrowed from national frameworks, meaning that they are permanent and unconditional; thus creating moral hazard in a multinational environment. This kind of solution is unpractical at EU level, for the shared identity among Euro Area countries is not enough developed; in the words of the ECB president, Mr. Draghi:

'In other political unions, cohesion is maintained through a strong common identity, but often also through permanent fiscal transfers between richer and poorer regions that even out incomes ex post. In the euro area, such one-way transfers between countries are not foreseen' (Draghi 2015a).

For a solution to address the flaws of both previous schemes, it should be non-discretional, in the sense that it would not need a case-by-case approval typical of inter-national schemes; but -being moral hazard a real problem outside polities with a strong shared identity- it would be conditional, meaning that active, corrective behavior will be required on the side of the recipients. Conditionality, on the one hand, and non-discretionality, on the other, would mark a departure from both national and inter-national solidarity approaches. It would be equal to say: a set of rules for joint solidarity is set so that in the 
extent you fulfill the duties the rules assign to you, you will enjoy solidarity without political discretion. Non-discretionality and conditionality seem to provide practical meaning to the idea of federative solidarity, which aims to build identity by co-determining responsibility and solidarity.

\subsection{Federative solidarity and the Samaritarian dilemma}

We believe that federative solidarity could be naturally implemented in the existing governance structure of the EU -built around the European Semester of Policy Coordination- in particular by introducing a financing vehicle for the implementation of country-specific recommendations. The disbursements would cover the priorities identified by the European Commission and the European Parliament each year and would target member states that -having received a recommendation concerning the given prioritysucceed in implementing it into their national framework. A proposal following these lines was advanced by the communication of the European Commission of $20^{\text {th }}$ March 2013, on the creation of a "Convergence and Competitiveness Instrument", which however was not taken up by member states as for today. The scheme would be automatic but would deal with moral hazard by ex-post refunding after project completion and evaluation; thus constituting a divergence both from national and international schemes of solidarity. A proposal with an even more pronounced supranational nature is the creation of a European unemployment benefit scheme (EUBS) which would directly target individuals. Depending on the design of the scheme, the monetary disbursements may be automatic but would also require (as it happens already within certain member states) an active stance of the recipient in job-seeking activities. Finally, a debt-mutualisation instrument such some forms of Eurobonds may be constructed with built-in supranational features.

At this regard a common guarantee could be created for bills emitted by member-states for the share of their expenditure which falls into a fully-coordinated process where policy contents and spending targets are the result of a shared, iterative decisional mechanism (Nicoli, 2013). By adapting the European Semester it is possible to create a true system of economic governance for which, by October each year, member states achieve a set of fully coordinated budgets and expenditure ceilings; bills emitted accordingly would enjoy seniority status and be fully guaranteed by a Union institution (like the ESM); bills emitted outside of the coordination framework, on the other hand, would be junior in respect to 
their counterpart and not being shielded by the Union institutions. The combination of these two forms of bills echoes the "blue bonds, red bonds" proposal advanced by Weizsäcker and Delpla (2010; 2011) although the scheme would concern only newly emitted debt and the attribution mechanism of the red/blue status would follow the abovementioned rules. In such scheme, the moral hazard would be dealt with by linking the solidarity implicitly in the mutualisation scheme to successful coordination, removing the risk of free-riding, without endangering the automaticity of the system (Nicoli, 2013).

In conclusion, a properly designed federative solidarity scheme would strongly mitigate the European Samaritarian Dilemma by creating a conditional but non-discretional transfers system. While it would constitute a real problem if supranational solidarity were to be a simple transposition of national schemes into the supranational arena without the (fictional) protection of the demos, by borrowing some features by inter-national schemes, a properly designed federative solidarity mechanism could create, over time, a degree of protection similar to existing national schemes without the need of pre-existing national identity, which is -up to a certain extent - substituted by the active behavior of the recipient. Moreover, by co-determining increasing degrees of mutual responsibility and generosity it would build up a common European identity which could allow for stronger solidarity in the future without undermining its sustainability today.

\section{European Solidarity and optimal allocation of resources: "the myth of the efficient markets"}

A third criticism to the creation of solidarity mechanisms at the Euro Area level argues that the real market conditions are being distorted by artificially providing financing streams to states and institutions. This distortive effect is supposed to work through three main channels: (a) by distorting efficient allocation of resources (for example, by investing in underproductive sectors or countries); (b) by distorting competition (for example by subsidizing troubled banks or companies which would otherwise go out of the market); and (c) by providing wrong incentives to governments (for example by artificially decreasing market financing rates for public bonds). These effects are deemed to concern both risk-sharing solidarity schemes, and transfer-subsidies from the center to the periphery. 
On the one hand, it is argued that -when a risk-sharing mechanism is in place- risk cannot be adequately internalized by financial institutions, leading to the creation of bubbles that would not exist otherwise. In other words, solidarity (and other forms of risksharing mechanisms) would distort the functioning of otherwise efficient markets, weakening the capacity of the financial system to respond to signals and adapt portfolios before the crisis actually happens, de facto preventing it. The underlying theory is known as "efficient market hypothesis" developed by economist Eugene Fama (Fama, 1965): according to the hypothesis, financial markets price-in all available and relevant information, so in a world with perfect information financial crises should never happen. By distorting the degree of information provided to the markets through risk-sharing mechanisms, the capacity of the markets of anticipating, and thus prevent, a financial crisis is greatly reduced. It is worth noting that the efficient market hypothesis does not claim that markets are actually perfectly efficient, but that they would tend to be so if all relevant information were to be disclosed. A recurring example of this dynamics (although only loosely linked with solidarity mechanisms) concerns the dynamics of the yields on the 10years public bonds in the "good" EMU years, from 2001 to 2007 (figure 2). Among others, Beirne and Fratzscher (2013) suggest that the convergence of sovereign yields occurred in the period was the result of an implicit guarantee on public bonds within the Euro Area which led to a mispricing of sovereign risk. In other words, financial agents deemed the prohibition of monetary financing included in article 123 TFEU, and the prohibition of debt mutualisation in article 125 TFEU, not credible; they expected that, if a country of the monetary union were to fall into a financial crisis, institutions would have played their part; hence the collapse of borrowing costs across peripheral countries down to the German level from 2001. The implicit guarantee expected by the markets led them to behave as if a Greek public bond were as risky as a German one, notably until the outbreak of the crisis when it became clear that no implicit guarantee was in place.

De Grauwe and Ji (2013 a) find evidence of the bubble-like behavior of public bonds before the crisis and explain the burst as a sudden realization, by financial agents, that a liquidity crisis can in fact happen, thus transforming the liquidity crisis into a solvency crisis. On the other hand, it can be argued that subsidies and transfers may also have distortive effects: by artificially providing a stream of resources, subsidies and transfers allow the peripheral country to enjoy -for the same level of services- a lower tax rate; this 
in turn produces a distortion in the allocation of investment, as returns are deemed to be higher in a subsidized sector than elsewhere. It must be noted that, although article 107 of TFEU bans any form of market-distorting subsidy, such a result would nevertheless stem from a transfers system, because the recipient countries would be allowed to reduce taxation. In this line of reasoning, capitals that would have been invested in more productive regions and sectors are instead invested in the less productive, subsidized regions and sectors because equalizing transfers make up for the difference. If the transfers were not to be in place, the investment would have occurred in the more productive economy, producing an overall higher growth rate.

At national level the market-distortive characteristics of both forms of solidarity mechanisms are either accepted on behalf of the shared identity of the demos, or off-set by other institutions. In the case of risk-sharing mechanisms, for instance, the main cost is associated with a sudden realization of financial actors of the weakness of the system; but nation states are usually able to cope with average-sized financial shocks through monetary policy and banking unions.

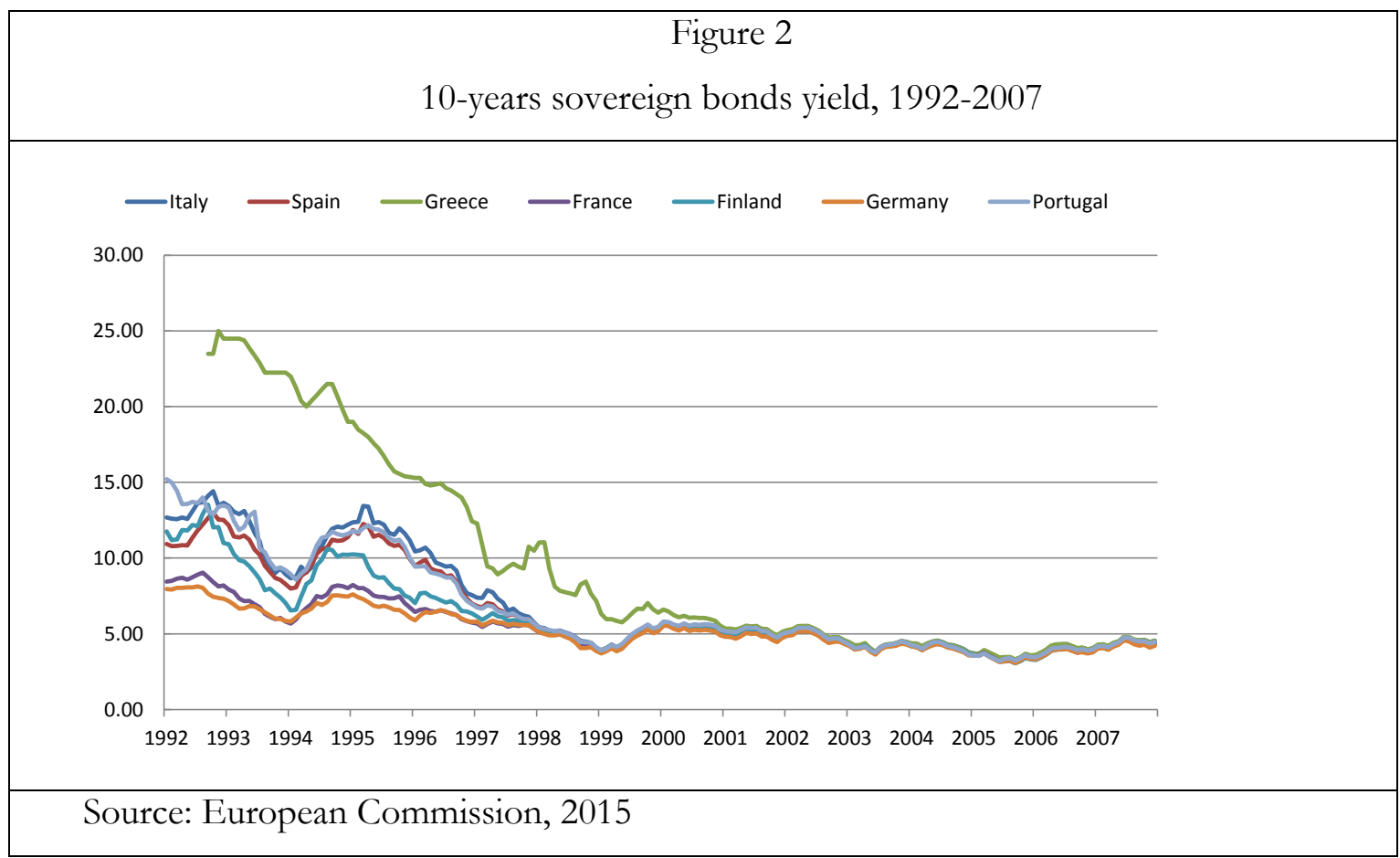

In the case of transfers and other forms of regional subsidies, the distortion of competition and the sub-optimal allocation of resources is often not dealt with; this in turn 
does indeed produce distortion and -through the previously-discussed moral hazard issuesthe iteration of the problems that caused the situation of need at the origins. This, however, is accepted on behalf of the nation: the distortive effects of subsidies are a cost that polities are willing to pay to ensure that the less advantaged of its members receive what they need.

On the international stage, the market-distortive effects of solidarity measures may be limited. Although there is a wide literature on the issue of the effects of international aid (cf., among many others: Economides, Kalyvitis and Philippopoulos, 2008; Peterman, 2013 for tied-aid practices) it mainly refers to the distortion happening within the recipient economy, not between the developed and developing countries. This is due, in particular, to two reasons: on the one hand, international solidarity measures between developed countries tend to be ad hoc, temporary, and conditional; thus, the distortive effect, when existing, is limited in time. On the other hand, international solidarity measures between countries with very large development gaps have a longer timeframe; however, the development gap is often so wide that the two countries would anyway not be in competition in the capital markets for resources allocation. ${ }^{\text {IX }}$ Moreover, international development aid can often be qualified as tied aid (Peterman, 2013) so the donor country makes up in additional demand for domestic production what it loses in potential investment. In general, if we consider the two features (ad-hoc, conditionality) of international solidarity, we can safely conclude that optimal resources allocation does not constitute a big issue as long as conditionality is set to resolve the ad-hoc situation that generated the need for support in the first place; in other words, if conditionality strengthens market conditions, investment in the country would no longer be sub-optimal. Conditionality is key to ensure that any ad-hoc funding does not translate into a permanent stream of public resources, as it happens in national, non-conditional systems. However, the particular nature of inter-national solidarity schemes renders this typology of agreements inefficient to deal with the problems faced by the Euro Area, for which a permanent solution is needed.

The question is, thus, whether a federative solidarity scheme can address the Euro Area issues without suffering from the flaws which characterize national and inter-national systems when dealing with optimal resources allocation. Can the Eurozone be saved without producing a distorting effect on markets? The Eurocrisis case is a particularly 
powerful example: in fact, the supporters of the efficient markets hypothesis implicitly argue that the system would be in general better off if resources were invested where they are more productive instead of being used to ensure solvability of peripheral countries. However, as De Grauwe (1998) already noticed, the issue was not that resources where flowing into less productive markets, but that they were flowing in markets where the high returns were associated with non-productive investment (like housing) fuelling a housing bubble without strengthening a country's productivity, especially in the Spanish case. Moreover, a narrow interpretation of the hypothesis leads to assume that the mistake was in considering a non-existing protection as real; if such a protection scheme were to exist, then the markets' choice would be efficient. The inefficiency, strictly speaking, was due to financial markets acting like a solidarity mechanism was in place, when actually none was. This problem can be solved in either way: by pushing the markets into realizing there is no solidarity mechanism in place (as they did) and thus restructuring their portfolios, or providing the missing solidarity mechanism. The landmark speech by ECB President Mr. Draghi in Summer 2012 clearly went in the latter direction, as well as the introduction of the OMT programme in late 2012, and of the Quantitative Easing in early 2015. Thus, the idea that solidarity distorted the markets before the crisis is simply wrong: the distortion was generated by an assumption, on the financial agents' side, about the implicit existence of a solidarity mechanism even when, in fact, the Treaties prohibited it.

The second concern related to the efficient markets' thesis is that investing resources into solidarity schemes will both 1) detour the same resources from more productive investments and 2) distort competition. However, when discussing the moral hazard issue, we found out that for moral hazard to be properly addressed, a degree of conditionality is needed. Moreover, we can also consider that if a solidarity mechanism were used to strengthen productivity and promote pro-market reforms, then it would not be considered as decreasing the efficiency of the market but instead strengthening it. In other words, to achieve an effective and non-distortive solidarity mechanism, the contents of conditionality should be linked to productivity-strengthening policies, so that not only the incentive for the recipients to rely on solidarity transfers tends to be removed over time, but that it is comparatively efficient to use resources to achieve this goal.

In sum, if we consider a situation in where 1) a solidarity scheme is in place effectively removing risk from distressed countries, 2) this solidarity is conditional to governmental 
(or individual) action, and 3) the contents of the conditional action improve productivity and/or market efficiency, then the three versions of the efficient markets' hypothesis opposition against EU-wide solidarity would be dealt with. It would actually be inefficient, for financial markets, not to invest in the distressed countries if pro-market, conditional solidarity is in place. In a normal inter-national scheme this would not be achievable, because the size and nature of fiscal integration needed at the Euro Area is out of reach of politically-brokered ad hoc transfers; in a national situation, the market distortion produced by unconditional, permanent solidarity schemes is ignored and its costs accepted on behalf of national unity. At Euro Area level, where automatic transfers are needed, productivityimproving conditionality attached to the transfers would produce efficient outcomes without creating under-productive market distortions. Market-oriented federative solidarity would therefore produce results putting the whole economy better-off of both situations where there is no solidarity in place, and situations where national-organic, non-conditional forms of solidarity exist.

\section{Beyond national-international solidarity dilemma: federative solidarity as a pathway towards a common European identity}

Solidarity is a necessity for contemporary Europe. Not only is it required to permanently stabilize the Eurozone, but it is a core element of both the European treaties and all national Constitutions. Unfortunately, the dichotomy between the "inter-national" solidarity of the Treaties and the "national-organic" solidarity of the Constitutions prevents a stable solution of the crisis. If Europe were to continue with this classical understanding of solidarity, then as long as we maintain that Europeans are not a demos and that such a form of solidarity is impossible outside of demoi, we would find that the monetary union cannot be saved; national-organic solidarity cannot be deployed outside the demos, and inter-national solidarity is ineffective. A simple extension of national solidarity to supranational would fail to address all three "Myths". While it would address the Euro Area's economic problems, a national-like scheme between different demoi will be unable to solve moral hazard and efficiency issues (because of its automaticity and nonconditionality) without providing the constitutional and philosophical "shroud" of the common demos. In other words, national-like solidarity would be politically unsustainable 
because it does not provide policies to address moral hazard but there is no justification for accepting the ensuing costs. It would be rejected by the people (who would be unwilling to "pay" for individuals they feel they share little with) and repelled by Constitutional Courts, because its automaticity would severely violate the unanimity needed for redistributive policies outside of the demos as set by the Bundesverfassungsgericht (2012). For nationallike solidarity schemes to be applied efficiently, legitimately, and sustainably at European level, a truly European demos is to be constructed; a demos which is yet to appear, as underlined, among many others, by the Bundesverfassungsgericht in 2009. Moreover, provided the definition of the demos we are used to -meaning a group of people linked by linguistic, cultural, religious and ethnical bonds- it can be argued, along with Weiler (2000) that such a demos is not to emerge in Europe.

\begin{tabular}{|l|l|l|l|}
\hline \multicolumn{5}{|c|}{ Table 1 } \\
\hline Solidarity principle & National & Inter-national & federative \\
\hline Range & Within nations & between nations & $\begin{array}{l}\text { Between citizens, } \\
\text { Despite nations }\end{array}$ \\
\hline activation & Automatic & ad-hoc & automatic \\
\hline Disbursements & Automatic & Conditional & $\begin{array}{l}\text { Conditional, market- } \\
\text { oriented }\end{array}$ \\
\hline $\begin{array}{l}\text { Problems when deployed at EU } \\
\text { level }\end{array}$ & $\begin{array}{l}\text { Unsustainable, effective, } \\
\text { inefficient, illegitimate } \\
\text { (but effective in } \\
\text { solving the crisis) }\end{array}$ & $\begin{array}{l}\text { Sustainable and efficient, } \\
\text { but either illegitimate or } \\
\text { non-effective in solving } \\
\text { the crisis }\end{array}$ & $\begin{array}{l}\text { Sustainable, efficient, legitimate? } \\
\text { Examples }\end{array}$ \\
$\begin{array}{l}\text { National Pension } \\
\text { System; National } \\
\text { unemployment } \\
\text { Insurance }\end{array}$ & $\begin{array}{l}\text { ESM financing; } \\
\text { international aid. }\end{array}$ & $\begin{array}{l}\text { Structural funds; deficit- } \\
\text { linked Eurobonds; } \\
\text { certain kinds of EUBS }\end{array}$ \\
\hline
\end{tabular}

If national-like solidarity mechanisms were to be chosen, then a different determining principle for the Eurodemos is to be created; a principle which, despite the numerous attempts, is yet to be individuated. In sum, national-like solidarity schemes would address the economic needs of the Euro Area, but would fail to be legitimate (both politically and constitutionally) as they would be neither efficient nor sustainable, with no Eurodemos as a backstop. Similarly, adoption of inter-national forms of solidarity to address the Euro Area's woes is unpractical. For the Euro Crisis to be solved, a proper fiscal union is needed. However, as exemplified by the decision of the Bundesverfassungsgericht in 2012, inter-national solidarity is characterized by a null transfer of sovereignty, by its ad-hoc 
activation and by its strict conditionality.

While conditionality is an essential feature for dealing with moral hazard and optimal resources allocation in a non-national environment, the ad-hoc, temporary nature of international solidarity renders this approach useless to solve the crisis. By making the activation of each single disbursement subject to a veto power exerted by each national parliament involved, inter-national solidarity applied in normal times would simply not work: we can only imagine how politically sustainable a joint unemployment scheme, or pension fund would be, whose payments towards the entitled individuals are subject, each and every time, to the unanimous approval of all European Union Parliaments. While addressing, thanks to conditionality, the myths of the beggar and the myth of efficient markets, international solidarity fails to address the fiscal needs of the Euro Area in the extent national solidarity would do. So while international-like solidarity schemes would be sustainable and efficient, they would either fail to address the Eurocrisis, or be illegitimate in front of Constitutional Courts.

Against this background, we argue that, for the monetary union to be saved, our understanding of the core logics behind the Myth of the demos as a foundation and condition for social solidarity has to change. By considering solidarity and identity co-determined, in the convincement that solidarity creates identity as much as it requires it, we develop a concept of federative solidarity which is originally anchored into classical social contractualism and not into "romantic" visions of the nation, but that contributes to develop a shared identity the more responsibility and generosity progress together. Our so-defined federative solidarity would then incorporate both elements stemming from national-organic solidarity, and conditional solidarity typical of inter-national settings. Federative solidarity transfers would therefore be automatic, i.e. not subject to the approval of each single Parliament of the Monetary Union each time a disbursement is made (against what decided by the Bundesverfassungsgericht in the 2012 ESM decision). However, they also would not be unconditional, as it is often the case in national systems. Individuals (more than the states, as it is the case for the inter-national schemes of solidarity created during the crisis) would be the subjects of such conditionality by being directly bound to each other into a European social contract, thereby acquiring rights (to the solidarity transfers) and individual duties to be fulfilled in order to be eligible for the transfers. Of course, this would require a reversal of the demos thesis, for which eligibility to automatic solidarity schemes is dependent from 
the demos of belonging. In federative solidarity schemes, the willingness to take an active role into the social contract becomes the condition for eligibility; the construction of the shared identity stems from the mutual responsibility built over time. In this, it would also differ from classical national-organic visions of solidarity, because it will be grounded into social contractualism and not on kin. Finally, it would differ from inter-national solidarity, because -despite the presence of conditionality- on the one hand it applies directly to individuals, and, on the other hand, it will be designed as a permanent instrument (which is also a condition for the monetary union to work properly).

As we have shown, a federative solidarity approach is optimal in respect to both previous approaches not only in the extent it allows for stronger solidarity among societies otherwise disconnected; it also reinforces the sense of common belonging over time (instead of weakening it) by overcoming typical limitations of national-organic solidarity, such as moral hazard and inefficient allocation of resources. Finally, the creation of a federative solidarity mechanism would boost the legitimacy of the European construction as a whole, by providing renewed output legitimacy in its early stages, and by posing the conditions for a common identity required for input legitimacy thereafter. In front of the growing need for the creation of a full-fledged fiscal union in the Euro Area endowed with redistributive powers, this paper has challenged the view that European redistributive measures -if properly designed- would be illegitimate, unsustainable, and inefficient. The rejection of supranational stabilization mechanisms is due to the failure to recognize that supranational solidarity cannot simply represent the translation of national schemes at supranational level, but shall borrow from both classical and international solidarity schemes, and requires the development of a new paradigm of mutual generosity-for-responsibility, which, over time, would lay the foundations of shared identity on the once-parted European continent.

\footnotetext{
* Francesco Nicoli is PhD Researcher at the University of Trento - School of International Studies.

${ }^{I}$ It can be argued, however, whether to apply a radical or moderate version of this principle. If solidarity is regarded as the provision of resources with a loss, it then becomes a concept relative to the market return rate; so lending money to a partner at a lower cost than the market return rate would still constitute a measure of solidarity even if it implies a positive return, as the lender is willing to accept a loss.

II It is worth noting that the authors of this paper don't agree with the theoretical argument and theoretical implications of the "no-demos thesis", and especially not with its ethnic/linguistic version. However, the reality of todays' politics renders impossible to exclude it from any analysis because the belief in the no-demos thesis is widespread and must be reckon with.

III Indeed, the reasoning of the Bundesverfassungsgericht is as follows. According to Lisbon (2009: 252), any fiscal decision must be approved by a Parliament and not by a Governments. Provided the absence of a European public sphere and appropriate representative institutions (assessed, again, in Lisbon) the only
} 
representative institution legitimized to approve a redistributive decision is the German Parliament. The requirements for a supranational representative institution to take over are unchanged in respect to Lisbon: the European Parliament still lacks adequate representativeness and a truly European Public sphere. Lacking these elements, there is no functional Euro-demos in which the German demos is adequately participating and represented, and thus the German Parliament is the one in charge of redistributive decisions.

IVThese issues have been largely dealt within international law jurisprudence in relation with the right to secession, which is generally recognized only in four cases: agreement between local authorities and central government; cases of lack of constitutionally-guaranteed local autonomy (failure in protecting the fundamental right of self-determination), in the case of oppressed populations during the era of colonization, and in case of ethnic cleansing ("remedial secession").

VIt is worth noting that while, the Trilemma may recall a similar conceptual framework developed by Rodrik (2011) and applied to the European Union by Crum (2013) in fact it differs in several aspects. As discussed in Nicoli (2015), two fundamental distinctions exist: first, differently from Rodrik/Crum framework, not any level of economic integration puts in question the democratic legitimacy of a political system: only institutions and policies with clear redistributive implications (Majone, 1999; 2014, Bundesverfassungsgericht, 2009). Second, Rodrik/Crum consider that "nation-states" should be considered as a vertex of the trilemma. In fact, we argue that nation-states constitute a solution, rather than a vertex, of the trilemma. In a nation-state, democracy is in functional equilibrium, because redistributive functions are held at the same level of democratic institutions, legitimated by a single demos. Creating a Euro-demos would solve the trilemma by getting rid of the "no-demos" (which is substituted by a "Euro-demos") and not of the "nation-state", which is simply shifted upwards. The opposite is untrue: eliminating the very notion of "nation-state", failing, however, to create a demos would fail in solving the issue.

VI To save the monetary union we need a fiscal union; fiscal union implies redistribution which, according with modern understanding of democracy, should be democratically legitimized; but such a democratically legitimized fiscal union would require majority voting, which- accordingly with the proponents of the Thesis, is impossible outside of a demos. We could therefore proceed with a democratic legitimized fiscal union if we give up the demos theory, or we could proceed with non-democratic fiscal union maintaining individual national sovereignty but giving up democracy on a fundamental issue such as fiscal and economic policy; finally, we could dismantle the monetary union tout court maintaining democracy and the demos thesis unaffected. For a detailed discussion of the legitimacy trilemma, including the differences with Rodrik (2011) global economy trilemma, please refer to Nicoli (2015).

VII We often self-justify ourselves when we limit our contributions to people asking for money in the streets by believing that our only result would be to remove their incentive to find a job of their own.

VIII In fact, this is changing even within unitary states, especially in relation to welfare programmes where moral hazard is most harmful, like in unemployment insurance schemes; several European countries have in place unemployment insurance schemes that, albeit automatic, require active behavior on the side of the recipient.

IX Note that, in this case, there is still a distortive effect- that given the higher productivity and expected returns in a developed economy, resources would still be best invested there.

\section{References}

- Agné Hans, 2007, 'The Myth of International Delegation: limits and suggestions for Democratic Theory in the context of the European Union', Government and Opposition, XLII(1): 18-45.

- Alt James, Lassen David Drayer and Wehner Joachim, 2012, 'Moral Hazard in an Economic Union: Politics, Economics, and Fiscal Gimmickry in Europe', Political Science and Political Economy Working Paper, No. 05/2012, London School of Economics, Department of Government.

- Basu Kaushik and Stiglitz Joseph, 2013, 'International Lending, Sovereign Debt and Joint Liability: and economic theory for amending the Treaty of Lisbon', World Bank Policy Research Working Paper Series, No. 6555, The World Bank.

- Beirne John and Fratzher Marcel, 2013, 'The pricing of Sovereign risk and contagion during the European Sovereign debt Crisis', European Central Bank, ECB Working Paper Series, No. 1625. 
- Belke Ansgar and Venheyer Florian, 2013, 'Doomsday for the Euro Area: Causes, Variants and Consequences of Breakup', International Journal of Financial Studies, I(1): 1-15.

- Brunkhorst Hauke, 2005, Solidarity: From Civic Friendship to a Global Legal Community, MIT Press, Cambridge.

- $\quad$ Bruter Michael, 2003, 'Wining hearts and minds for Europe: the impact of news and symbols on civic and cultural European Identity', Comparative Political Studies, XXXVI(10): 1148-1179.

- Bryde Brun-Otto, 1994, 'Die bundesrepublikanischeVolksdemokratie als Irrweg der Demokratietheorie', Staatswissenschaften und Staatspraxis: rechts-, wirtschafts- und sozialwissenschaftliche Beiträge zum staatlichen Handeln, V(3): 305-330.

- $\quad$ Bundesverfassungsgericht, 1993, Decision of October 12, 1993, "Maastricht".

- Bundesverfassungsgericht, 2009, Decision of June 30, 2009, “Lisbon”.

- Bundesverfassungsgericht, 2012, Decision of October 10, 2012, “ESM".

- Closa Carlos and Maatsch Aleksandra, 2013, 'In a Spirit of Solidarity? Justifying the European Financial Stability Facility (EFSF) in national parliaments' debates', Journal of Common Market Studies, LII(4): 826-842

- Cohon Rachel, 2001, 'The Shackles of Virtue: Hume on Allegiance to Government', History of Philosophy Quarterly, XVIII(4): 393-413

- Cohon Rachel, 2010, 'Hume's Moral Philosophy', in Zalta Edward (ed), The Stanford Encyclopedia of Philosophy, Fall 2010.

- Crum Ben, 2013, 'Saving the Euro at the Cost of Democracy?', Journal of Common Market Studies, LI(4): 614-630.

- $\quad$ De Grauwe Paul, 1998, 'The Euro and the Financial Crises', Financial times, 20 February 1998.

- $\quad$ De Grauwe Paul, 2003, Economics of Monetary Union, Oxford University Press, Oxford.

- De Grauwe Paul, 2011, 'Governance of a Fragile Eurozone', CEPS working document, No. 346/May 2011.

- $\quad$ De Grauwe Paul, 2013, 'Design Failures in the Eurozone- can they be fixed?', Economic Papers No. 491, European Economy, April 2013.

- De Grauwe Paul and Yuemei Ji, 2013a, 'Self-fulfilling crises in the Eurozone: an empirical test', Journal of International Money and Finance, Vol. 34, April 2013: pp. 15-36.

- De Grauwe, Paul and Yuemei Ji, 2013 b, Fiscal implications of ECB's bond buying programme. Vox Policy Portal, June 14th, 2013. 03/2010.

- Delpla Jacques and Weizsäcker Jacob, 2010, 'The blue bond proposal', Bruegel policy Brief, Issue

- Delpla Jacques and Weizsäcker Jacob, 2011, 'Eurobonds: the blue bonds concept and its implications', Bruegel Policy Contribution, Issue 02/2011.

- Deo Stephane, Donovan Paul and Larry Hathaway, 2011, Euro Break-Up - The Consequences. Global Economic Perspectives, UBS Investment Research Department, London.

- Derpmann Simon, 2009, 'Solidarity and Cosmopolitanism', Ethic Theory and Moral Practice, Issue 12: 303-315.

- Dowd Bryan, 1982, 'The logic of moral hazard: a game-theoretical illustration', The Journal of Risk and Insurance, XLIX(3): pp.443-447.

- $\quad$ Dowd Kevin, 2009, 'Moral Hazard and the Financial Crisis', Cato Journal XXIX(1).

- Draghi Mario, 2015a, 'Stability and Prosperity in the Monetary Union', Project Syndicate, 2nd January, 2015.

- Durkheim, Emile, 1893, De la division du travail social, Félix Alcan, Paris. Available for download at http://classiques.uqac.ca/classiques/Durkheim_emile/division_du travail/division travail.html.

- $\quad$ Economides George, Kalyvitis Sarantis and Philippopulos Apostolis, 2008, 'Do Foreign Aid Transfers Distort Incentives and Hurt Growth? Theory and Evidence from 75 Aid-recipient Countries', Public Choice, CXXXIV(3): 463-488.

- $\quad$ Eichengreen Barry, 2008, 'The breakup of the Euro Area', NBER working Paper No. 11393.

- Enderlein Henrik (ed), 2012, Completing the Euro: a roadmap towards fiscal union in Europe, Report of "Tommaso Padoa-Schioppa" Group, Notre Europe. 
- Fabbrini Sergio, 2012, Intergovernmentalism and its outcomes: the implications of the Euro Crisis on the European Union, Draft working paper, University of California.

- $\quad$ Fama Eugene, 1965, 'The behavior of stock-market prices', The Journal of Business, XXXVIII(1).

- Follesdal Andreas and Hix Simon, 2006, 'Why there is a democratic deficit in the EU: a response to Majone and Moravcsik', Journal of Common Market Studies, XLIV(3): 533-562.

- Friedrich Dawid and Kröger Sandra, 2013, 'Democratic Representation in the EU: two kinds of subjectivity', Journal of European Public Policy, XX(2): 171-189.

- $\quad$ Gould, Carol, 2007, 'Transnational Solidarities', Journal of Social Philosophy, XXXVIII(1): 148-164.

- Grimm Dieter, 1995, 'Does Europe need a Constitution?', European Law Journal, I(3): 282-302.

- Haas Ernst, 2008 (1964), Beyond the Nation State. Functionalism and international organization, European Consortium for Political Research Press, Colchester.

- Habermas Jürgen, 2011, 'Europe’s post-democratic era', The Guardian, 10 November 2011.

- Habermas Jürgen, 2013, Democracy, Solidarity and the European Crisis, Guest Lecture, University of Leuven, April 26th, 2013.

- Hix Simon, 1998, 'Elections, Parties and Institutional Design: A Comparative Perspective on European Democracy', Western European Politics, XXI(3): 19-52.

- Hix Simon, Noury Abdul and Roland Gérard, 2007, Democratic Politics in the European Parliament, Cambridge University Press, Cambridge.

- Kawai Masahiro and Akiyama Shigeru, 2003, 'Implication of the currency crisis for exchange rates arrangements in emerging East Asia', World Bank Policy Research Working Papers Series.

- Kielmansegg Peter, 1994, 'Läßt sich die Europäische Gemeinschaft demokratisch verfassen?', Europäische Rundschau, XXII(2): 23-33.

- Kielmansegg Peter, 1996, 'Integration und Demokratie', Jachtenfuchs Markus and Kohler-Koch Beate (eds), Europäische Integration, Springer, Heidelberg, 47-71.

- Kontochristou Maria and Mascha Evi, 2014, 'The Euro Crisis and the Question of Solidarity in the European Union: Disclosures and Manifestations in the European Press', Review of European Studies, VI(2).

- Lacombe Clément and Lemaitre Frédéric, 2012, Interview with Jens Weidmann, Le Monde, May 26th, 2012.

- MacIntyre Alasdair, 1981 (3rd edition, 2007), After Virtue: A Study in Moral Theory, University of Notre Dame press, Notre Dame, Indiana.

- MacNamara Kathleen, 2002, 'Rational fictions: central bank independence and the social logic of delegation', West European Politics, XXV(1): 47-76.

- Majone Giandomenico, 1999, 'The regulatory state and its legitimacy problems', Western European Politics, XXII(1): 1-24.

- Majone Giandomenico, 2014, 'From a Regulatory State to a Democratic Default', Journal of Common Market Studies, LII(6): 1216-1223.

- Meade James, 1957, 'The Balance-of-Payments problems of a European Free-Trade Area', The Economic Journal, LXVII(no. 267): 379-396.

- Ménéndez Augustin, 2000, 'Another view of democratic deficit: no taxation without representation', in Joerges Christian, Mény Yves and Weiler J.H.H. (eds), 2000, What kind of Constitution for what kind of polity? Responses to Joschka Fisher, The Robert Schuman Centre for Advanced Studies; The European University Institute; Harvard Law School. Firenze, 126-138.

- Merler Silvia and Jean Pisani-Ferry, 2012, 'The Euro Crisis and the new impossible trinity', Bruegel Policy Contribution, Issue No. 1, January 2012.

- Moravcsik Andrew, 2002, 'In defence of the "Democratic Deficit": reassessing legitimacy in the European Union', Journal of Common Market Studies, XL(4): 603-24.

- Mundell Robert, 1960, 'The Monetary Dynamics of International Adjustment Under Fixed and Flexible Exchange Rates', The Quarterly Journal of Economics, LXXIV(2): 227-257.

- Mundell Robert, 1961, 'A Theory of Optimal Currency Areas', American Economic Review, LI(4): 657665.

- Nicolaidis Kalypso, 2013, 'European Demoicracy and its crisis', Journal of Common Market Studies, LI(2): 351-369. 
- $\quad$ Nicoli Francesco, 2013, Pathways for a Genuine Fiscal Union, EPC Policy Brief, June 2013.

- Nicoli Francesco, 2016, 'Democratic Legitimacy in the Era of Fiscal Integration', in Krieger Tim, Panke Diana and Neumaker Bernhard (eds), Europe's Crisis: the conflict-theoretical perspective, Nomos Publishing, Baden-Baden (forthcoming).

- Peterman Jan-Henrik, 2013, Between Export Promotion and Poverty Reduction: the foreign economic policy of untying official development assistance, Springer, Heidelberg.

- $\quad$ Pisani-Ferry Jean, Vihriälä Erkki and Wolff Guntram, 2013, 'Options for a Euro Area fiscal capacity', Bruegel Policy Contribution, No.02/2011.

- Pisani-Ferry Jean and Wolff Guntram, 2012, 'Fiscal implications of a Banking Union', Bruegel Policy Brief, Issue No. 02, September 2012.

- $\quad$ Raunio Tapio, 1999, 'Always a step behind? National legislatures in the European Union', Government and Opposition, XXXIV(2): 180-202.

- $\quad$ Rawls John, 1971, A Theory of Justice, The Belknap Press of Harvard University Press, Cambridge.

- $\quad$ Rodrik Dani, 2011, The Globalization Paradox: democracy and the future of world economy, Norton eds., New York.

- $\quad$ Scharpf Fritz, 1970, Demokratietheorie zwischen Utopie und Anpassung, Universitätsverlag, Konstanz.

- Scharpf Fritz, 1998, Interdependence and democratic legitimation, MPIfG Working Paper No.98/2, September 1998.

- $\quad$ Scharpf Fritz, 2009, Legitimacy in the Multilevel European Polity, MPIG Working Paper, 2009/01.

- Schmitter Philippe, 2002, 'Neo-Neo-Functionalism', Working Paper for the publication in Wiener Antje and Diez Thomas (eds), 2009, Theories of European Integration, Oxford University Press, Oxford.

- Serricchio Fabio, Tsakatika Myrto and Quaglia Lucia, 2013, 'Euroscepticism and the Global Financial Crisis', Journal of Common Market Studies, LI(1): 51-64.

- $\quad$ Sinn Hans-Werner and Wollmershäuser Timo, 2011, 'Target Loans, Current Account Balances and Capital Flows: The ECB's Rescue Facility’, CESifo Working Paper Nr. 3500, 24 June 2011.

- Szczerbiak Aleks and Taggart Paul, 2002, 'The Party Politics of Euroscepticism in EU member and Candidate states', SEI Working Paper No.51, Opposing Europe Research Network working paper No. 6.

- Van Rompuy Herman, 2012, Towards a Genuine economic Monetary Union, Report for the European Council of 27th and 28th June, 2012.

- Walzer Michael, 1983, Spheres of Justice: a defense of pluralism and equality, Basic Books inc. United States.

- Weiler J.H.H., 1995, 'Does Europe need a Constitution? Reflections on Demos, Telos and the German Maastricht Decision', European Law Journal, I(3): 219-258.

- Weiler J.H.H., 1996, 'European Neo-Constitutionalism: in Search of Foundations for the European Constitutional Order', Political Studies, XLIV(3): 517-533.

- Weiler J.H.H., 2000, Federalism without Constitutionalism: Europe's Sonderweg, in Nicolaidis Kalypso and Howse Robert (eds), The Federal Vision: Legitimacy and Levels of Governance in the United States and the European Union, Oxford University Press, Oxford, 54-70.

- Wolf Klaus Dieter, 1999, 'The new Raison d'Etat as a problem for democracy in world society', European Journal of International Relations, V(3): 333-363.

- Zürn Michael, 2000, 'Democratic Governance Beyond the Nation State: The EU and other International Institutions', European Journal of International Relations, VI(2): 183-221. 